$10-24-2019$

\title{
Indigenous and Crown Sovereignty in Canada
}

Kent McNeil

Osgoode Hall Law School of York University, kmcneil@osgoode.yorku.ca

Follow this and additional works at: https://digitalcommons.osgoode.yorku.ca/all_papers

Part of the Indian and Aboriginal Law Commons

\section{Repository Citation}

McNeil, Kent, "Indigenous and Crown Sovereignty in Canada" (2019). All Papers. 330.

https://digitalcommons.osgoode.yorku.ca/all_papers/330

This Conference Paper is brought to you for free and open access by the Research Papers, Working Papers, Conference Papers at Osgoode Digital Commons. It has been accepted for inclusion in All Papers by an authorized administrator of Osgoode Digital Commons. 


\section{Kent McNeil, "Indigenous and Crown Sovereignty in Canada", a talk given at the University of Saskatchewan College of Law, 24 October 2019}

Peter Russell, a prominent Canadian political scientist, tells of the time he met with Dene leaders on his first visit to the Northwest Territories in 1974. A Dene woman opened the discussion by asking: "Professor Russell, I have two questions for you: What is sovereignty? And how did the Queen get it over us?" Years later, he described his response: "For the first question, I had a nice, pat answer based on Bodin, Hobbes, and my understanding of European international law. But I stumbled over the second. The truth of the matter is that I didn't have a clue how Queen Victoria and her Canadian henchmen had 'got sovereignty' over the Dene."1 Later, he said he "came to know that the right answer to the Dene woman's second question was - in a word - 'trickery.' Or, to use the more ironic concept I learned from an Australian Aboriginal friend, it was 'the white man's legal magic' that did the trick."2

In international law, sovereignty entails exclusive authority over a territory and everyone and everything in it, independently of any other authority. In theory, at least, nation states are sovereign and equal. They are independent of one another and are not supposed to interfere in the internal affairs of other nation states.

This concept of state sovereignty has been breaking down somewhat in recent times. For example, by forming the European Union member states have given up some of their authority to the European Parliament, which is elected directly by approximately 375 million eligible voters. Discontent over this partial transfer of sovereignty to the European Parliament is one of the motivating forces behind Brexit in the United Kingdom.

Another way in which state sovereignty is being weakened is in the area of humanitarian intervention. The shocking mass killings in Rwanda in the1990s caused this question to be raised: In what circumstances do nation states have an obligation to intervene in the internal affairs of other states to stop serious abuses of human rights? At the 2005 World Summit of the United Nations, a global political commitment was endorsed, known as the Responsibility to Protect, to

\footnotetext{
${ }^{1}$ Peter H. Russell, "Doing Aboriginal Politics," (2001) 30:2 Canadian Political Science Association Bulletin 7-8.

${ }^{2}$ Ibid. at 8 .
} 
prevent crimes against humanity, including ethnic cleansing, genocide, and war crimes. $^{3}$

These inroads into state sovereignty are relatively recent developments. Earlier on, as the modern concept of sovereignty grew out of the creation of independent nation states in Western Europe, the absolute independence of nation states became a fundamental pillar of the law of nations, as international law used to be called. This system of states with legal personality in the European law of nations was acknowledged by the Treaty of Westphalia in 1648 .

Before proceeding further, I think it is important to make a couple of important distinctions. The first is between sovereignty, also called territorial title, and title to land. Sovereignty involves political jurisdiction - the authority to make and enforce laws and exercise administrative control over a territory.

Title to land involves property rights within a territory. Property rights are generally a matter of domestic law, whereas sovereignty is a matter of domestic and international law. Property can be either public - for example, Crown lands in Canada - or private, such as fee simple estates held by individuals or corporations.

So when the British Crown got sovereignty over Canada, it did not necessarily get title to all the land. If the Indigenous peoples had Aboriginal title, in Canadian domestic law all the Crown got in terms of property rights was the underlying or radical title, as a result of the common law doctrine of tenure. ${ }^{4}$

The other important distinction is between external and internal sovereignty. In international law, a sovereign has both - externally, it can interact with other sovereigns by entering into treaties, defending its borders, and so on. Internally, it has full governmental authority (subject today to the Responsibility to Protect and limitations in places like the European Union), but this authority can be divided, as it is in federal systems. In Canada, internal sovereignty is divided among the federal government, the provincial governments, and, I would argue, Indigenous governments. In the United States, it is divided among the federal government, the fifty states, the Indian nations, and, some would say, the people.

How do nation states acquire sovereignty over new territory? In international law, by what I would call either derivative or original means. In the past, if a territory

\footnotetext{
${ }^{3}$ United Nations Office on Genocide Prevention and the Responsibility to Protect, https://www.un.org/en/genocideprevention/about-responsibility-to-protect.shtml.

${ }^{4}$ Tsilhqot'in Nation v. British Columbia, [2014] 2 S.C.R. 257 at paras. 69-72.
} 
already had an acknowledged sovereign, another sovereign could take it by conquest or acquire it by a treaty of cession. These are derivative means, whereby sovereignty is either taken or transferred from a pre-existing sovereign.

If there was no acknowledged, pre-existing sovereign, the territory could be acquired by effective occupation, an original means. European nations also purported to acquire sovereignty over territories in other parts of the world by discovery, papal grants, symbolic acts of possession, and royal charters, but there was never any agreement over the effectiveness of these various means of asserting sovereignty. ${ }^{5}$

Prescription, another means of acquiring sovereignty, would appear to be derivative in the sense that there was a pre-existing sovereign, and original in the sense that sovereignty was acquired by effective occupation for a sufficiently long time, not by conquest or transfer from the earlier sovereign.

Getting back to North America, were the Indigenous peoples sovereign before the Europeans arrived? This takes us to the distinction between de facto and de jure sovereignty. De facto sovereignty depends on the actual exercise of authority on the ground. It involves control of a territory by (1) not allowing outsiders and goods in without permission (i.e., border control), (2) establishing and enforcing laws, (3) administrative action, and (4) in modern times, by construction of infrastructure such as railways and roads and by provision of government services such as a postal system, etc. But these kinds of factors have to be assessed in accordance with the society in question and their way of life, not by Eurocentric standards.

I have no doubt that the Indigenous nations had de facto sovereignty over their territories prior to European colonization. Although the boundaries may not have always been precise, those nations exercised political and physical control over specific territories and had laws governing the use of resources and the relationships among clans, families, and individuals. They entered into treaties with their neighbors and sometimes went to war with them. They may not have had a concept of sovereignty that was the same as the European concept that

\footnotetext{
${ }^{5}$ See John Thomas Juricek, "English Claims in North America to 1660: A Study in Legal and Constitutional History" (Ph.D. dissertation, University of Chicago, 1970); Patricia Seed, Ceremonies of Possession in European Conquest of the New World, 1492-1640 (Cambridge: Cambridge University Press, 1995); Brian Slattery, "Paper Empires: The Legal Dimensions of French and English Ventures in North America," in John McLaren, A.R. Buck, \& Nancy E. Wright, eds., Despotic Dominion: Property Rights in British Settler Societies (Vancouver: UBC Press, 2005), 50.
} 
became entrenched in the European law of nations around the time of the Treaty of Westphalia, but they exercised as much authority as European sovereigns exercised.

De facto sovereignty does not depend on the existence of any particular form of government - Indigenous peoples were organized politically and socially in vastly different ways. What matters is that they were organized socially and politically and exercised authority and control over their peoples and territories. This is the conclusion the International Court of Justice came to in 1975 in the Western Sahara case. ${ }^{6}$

The way authority was exercised in Indigenous nations was no doubt very different from the way it was exercised in Europe at the time of colonization of North America. Individuals usually had a lot more personal freedom than in Europe. Indigenous laws and social norms were not usually enforced by coercion, but by example, persuasion, shaming, ostracism, and so on. Only in extreme cases was corporal punishment or death administered. Imprisonment was not generally used as a form of punishment. Of course, the methods used to enforce Indigenous law could vary greatly from one nation to another.

The point is that the ways in which Indigenous nations governed themselves are not relevant to deciding whether they had de facto sovereignty. Instead, what counts is the fact that they did govern themselves by exercising political authority and controlling territory.

But did they have de jure sovereignty? To answer this question, one first has to ask, in what system of law, because de jure sovereignty, unlike de facto sovereignty, is relative.

The best example of the relativity of de jure sovereignty I have been able to find is the situation in Rhodesia - now Zimbabwe - in the period of the racist regime of Ian Smith from the time of the Unilateral Declaration of Independence (UDI) in 1965 to 1980.

There can be little doubt that the Smith regime had de facto sovereignty in Rhodesia after the UDI in 1965 (before that, Rhodesia had been a British colony). But what about de jure sovereignty? Well, it depends on what legal system one chooses to apply.

${ }^{6} 1975$ I.C.J.R. 12. 
In international law, Rhodesia was not a sovereign state because the international community did not accept the UDI and refused to recognize Rhodesia. Likewise in English law: English courts ruled that the UDI was illegal. But in Rhodesian domestic law, Rhodesia was a sovereign state because the local courts, after some hesitation, accepted the legitimacy of the Smith regime.

So we have a situation where de facto sovereignty resulted in de jure sovereignty in Rhodesia, but not in the United Kingdom or the rest of the world. So de jure sovereignty is a relative matter, depending on which legal system one chooses to apply.

Returning to North America, if the Indigenous nations had de facto sovereignty prior to European colonization, what system of law should be used to determine whether they had de jure sovereignty? Surely not the domestic law of the colonizing European powers - they exercised no authority in North America prior to colonization, so their laws could not have applied here.

What about international law? Colonization of North America began at the beginning of the $17^{\text {th }}$ century. At the time, international law - or the law of nations, as it was called up until around 1800 - was still in its infancy. It was still being developed by the nations of Europe to govern their relations with one another. Hugo Grotius' major work, On the Law of War and Peace, was only published in 1625, and the Treaty of Westphalia was not entered into until the middle of the $17^{\text {th }}$ Century.

Not only that, but the "nations" to which the "law of nations" applied were the European nations, not the Indigenous nations of North America. The Indigenous nations had no part in developing the law of nations and were simply outside its scope.

Natural law jurists such as Grotius may have thought that the law of nations was universal and applied throughout the world, but given that this law was used to justify colonialism it can hardly be regarded as being part of the natural order of things. Moreover, by the end of the $18^{\text {th }}$ Century, legal positivism had pretty much replaced natural law theories. For the positivists, like Jeremy Bentham who apparently coined the new designation "international law", this law came from the positive actions of states. It grew out of state practice and convention (treaties), rather than out of the natural order of the world. 
Given all this, the sovereign status of the Indigenous nations in North America cannot have been determined on the basis of the law of nations or international law. So for the Indigenous nations to have had de jure sovereignty prior to European colonization, it must have been in their own systems of law. There are two relevant systems here: (1) the domestic law of each Indigenous nation, and (2) the inter-nation law that governed their relations with one another.

But we do have to be careful here because Indigenous peoples may not have had a concept of sovereignty equivalent to the European concept, which as we have seen really developed after the emergence of independent nation states - in particular France, England, Spain, and Portugal - in the latter half of the Middle Ages. Nonetheless, the Indigenous nations of North America no doubt regarded themselves as independent entities that exercised authority over specific territories, which is what sovereignty is all about.

So to conclude this part, I think the Indigenous nations in North America had both de facto sovereignty and something resembling de jure sovereignty in their own systems of law at the time of European colonization.

Now let's come back to the second question the Dene woman asked Peter Russell: How did the Europeans acquire sovereignty in North America?

The answer Chief Justice Marshall of the Supreme Court of the United States gave in Johnson v. McIntosh ${ }^{7}$ in 1823 was "discovery". He said the colonizing European nations all agreed that sovereignty over territories occupied by Indigenous peoples in North America could be acquired by this means, but in fact there was no such agreement. As already mentioned, the European powers made conflicting claims based on discovery, papal grants, symbolic acts of possession, royal charters, and so on, without ever agreeing on the effectiveness of these various methods. In reality, effective occupation was the only means of original acquisition that came to be accepted and incorporated into international law.

Moreover, Marshall C.J.'s judgment is internally contradictory because he acknowledged the pre-existing sovereignty of the Indian nations. Discovery, when followed by possession, would have been an original means of acquiring sovereignty, but if the Indigenous peoples were sovereign before, then logically the European powers would have had to acquire sovereignty derivatively from them by conquest or cession.

\footnotetext{
${ }^{7} 8$ Wheat. (21 U.S.) 543 (1823).
} 
I think Chief Justice Marshall became aware of this contradiction in his judgment and sought to redress it nine years later in Worcester v. Georgia. ${ }^{8}$ In that case, he acknowledged that the Cherokees and other Indian nations were sovereign and independent prior to the arrival of the Europeans. The doctrine of discovery, he said in this case, applied only among the European nations that had agreed to it. Consistently with the international law rule that treaties bind only the parties, ${ }^{9}$ he acknowledged that the doctrine of discovery did not apply to the Indigenous nations because they had not agreed to it. Consequently, it could not have diminished their pre-existing rights, whether to sovereignty or to the lands they occupied and owned. In this way, I think Marshall C.J. acknowledged the relativity of de jure sovereignty. The de jure sovereignty the Europeans supposedly acquired by discovery applied only among themselves.

Unfortunately, Marshall C.J.'s new insight on this issue got ignored and the doctrine of discovery has become imbedded in American law as the foundation for American sovereignty over areas not acquired derivatively from France, Spain, Mexico, and Russia. It has been applied not only to the eastern Thirteen Colonies, but also to the Oregon Territory, which has been taken to have been acquired by the discovery of the estuary of the Columbia River by American Captain Robert Gray in 1792 and Lewis and Clark's overland journey to the Northwest Coast and back in 1804-1806.

The doctrine of discovery has been severely criticized ${ }^{10}-$ it is disgraceful that a doctrine based on racist perceptions of European superiority remains to this day the ground for American claims to sovereignty over the eastern United States and Oregon, Washington, and Idaho. The Truth and Reconciliation Commission in Canada, in its 2015 Report, also condemned the doctrine of discovery and recommended that it be discarded. ${ }^{11}$

So how did the Crown acquire sovereignty in Canada?

\footnotetext{
${ }^{8} 6$ Pet. (31 U.S.) 515 (1832).

${ }^{9}$ See Direct United States Cable Company v. Anglo-American Telegraph Company (1877), 2 App. Cas. 394 at 421 (P.C.); Clipperton Island Case (1932), 26 A.J.I.L. 390 at 394; Lord [Arnold Duncan] McNair, The Law of Treaties (Oxford: Clarendon, 1961), 309-21; Malcolm N. Shaw, International Law, 7th ed. (Cambridge: Cambridge University Press, 2014), 672-74.

${ }^{10}$ E.g. see Robert J. Miller, Jacinta Ruru, Larissa Behrendt, and Tracey Lindberg, Discovering Indigenous Lands: The Doctrine of Discovery in the English Colonies (Oxford: Oxford University Press, 2010).

${ }^{11}$ Canada, Final Report of the Truth and Reconciliation Commission of Canada, 6 vols. (Winnipeg: Truth and Reconciliation Commission, 2015) vol. 6 at 29-33, 37-38.
} 
The standard answer is that the British Crown acquired sovereignty in Acadia (Nova Scotia) by cession from France by the Treaty of Utrecht in 1713, and over the rest of French Canada by conquest on the Plains of Abraham in 1759 and cession from France by the Treaty of Paris, 1763. But how did France acquire sovereignty? Not by conquest of or cession from the Indigenous peoples, because that never happened. In the St. Catherine's case in 1887, Justice Taschereau of the Supreme Court of Canada said New France had been acquired by discovery, but in the appeal decision of the Judicial Committee of the Privy Council in London no reference was made to how France acquired its North American colonies. ${ }^{12}$

The rest of Canada was supposedly acquired by settlement, the British colonial equivalent of effective occupation. This implies that the Indigenous peoples were not sovereign, but of course this was only from the Crown's perspective. Acting on this assumption, Charles II, by Royal Charter in 1670, purported to grant all the lands draining into Hudson Bay and Strait, as well as governmental authority over that vast territory which was named Rupert's Land after the king's cousin, to a private company, the Hudson's Bay Company. At the time, all the English had done was sail around Hudson Bay, land at a few places and trade for furs, and establish a trading post at the mouth of the Rupert River. The interior and the extent of the Rupert's Land grant were entirely unknown to them.

What are we to make of this? Did the Crown already have sovereignty over this territory as a result of a few voyages of discovery into Hudson Bay? Did the Royal Charter itself extend Crown sovereignty over Rupert's Land? I think the better view is that the Charter was prospective - it gave the company the authority to take possession of Rupert's Land, if it was able to do so. This was the interpretation suggested by the Judicial Committee of the Privy Council in the Ontario Boundary Case of 1884, in comments to counsel during argument of the case. ${ }^{13}$

In actual fact, the Hudson's Bay Company did not take possession of much of Rupert's Land in the 200 years that it purported to hold the territory before surrendering it back to the Crown in 1870. Apart from the Red River Settlement at the forks of the Red and Assiniboine Rivers and the company's trading posts on

\footnotetext{
${ }^{12}$ St. Catherine's Milling and Lumber Company v. The Queen (1887), 13 S.C.R. 577, affirmed (1888), 14 App. Cas. 46 (P.C.).

${ }^{13}$ Ontario Boundaries Case (1884), implemented by Imperial Order-in-Council, 11 August 1884, in The Proceedings before the ... Privy Council ... Respecting the Westerly Boundary of Ontario (Toronto: Warwick and Sons, 1889), 416-18.
} 
Hudson and James Bays and at a few locations on rivers and lakes in the interior, the real possessors of the territory were the First Nations and the Métis.

In 1870, the Hudson's Bay Company surrendered Rupert's Land back to the British Crown, which then transferred it to Canada, along with the adjacent NorthWestern Territory. That's the usual story of how Canada acquired sovereignty over northern Ontario and northern Quebec, the Prairie Provinces, and the mainland territories north of the $60^{\text {th }}$ parallel.

Canada then entered into the eleven numbered treaties with the Indigenous nations in these territories. These agreements covered northern Ontario, the three Prairie Provinces, northeastern British Columbia, and part of the Yukon and the NorthWest territories. From the Crown's perspective, it already had sovereignty over these regions, but needed to enter into treaties to get surrenders of First Nation lands. The Indigenous peoples' understanding is different: they generally thought the treaties were political agreements between nations whereby they were agreeing to share sovereignty and land with the Crown and European settlers. ${ }^{14}$ These different understandings of the treaties remain unresolved to this day.

What about British Columbia?

It was a separate British colony that only joined Canada in 1871, four years after Confederation. It has generally been regarded as having been acquired by settlement, the equivalent of effective occupation in international law.

What has the Supreme Court of Canada had to say about this?

In the Sparrow decision in 1990, Chief Justice Dickson and Justice La Forest, for a unanimous Court, said in reference to British Columbia that "there was from the outset never any doubt that sovereignty and legislative power, and indeed the underlying title, to [Aboriginal title] lands vested in the Crown" (they did not specify when "the outset" might have been). ${ }^{15}$ For authority, they cited Johnson $v$. McIntosh, so they seem to have relied, at least implicitly, on the doctrine of discovery.

\footnotetext{
${ }^{14}$ E.g. see Harold Cardinal \& Walter Hildebrandt, Treaty Elders of Saskatchewan: Our Dream Is That Our Peoples Will One Day Be Clearly Recognized as Nations (Calgary: University of Calgary Press, 2000); James (Sákéj) Youngblood Henderson, Treaty Rights in the Constitution of Canada (Toronto: Thomson Carswell, 2007); John Borrows \& Michael Coyle, eds., The Right Relationship: Reimagining the Implementation of Historical Treaties (Toronto: University of Toronto Press, 2017).

${ }^{15}$ R. v. Sparrow, [1990] 1 S.C.R. 1075.
} 
Then in the Delgamuukw case in $1997,{ }^{16}$ and more recently in Tsilhqot 'in Nation in $2014,{ }^{17}$ the Court accepted 1846 as the year of Crown acquisition of sovereignty. Why 1846? That was the year of the Oregon Boundary Treaty, whereby Britain and the United States settled their claims over that part of North America and established the boundary along the $49^{\text {th }}$ parallel from the Rocky Mountains to the Strait of Georgia (now the Salish Sea). This extended the international boundary that had previously been established along the $49^{\text {th }}$ parallel from the Lake of the Woods to the Rocky Mountains when these two nation states entered into the Convention of Commerce in 1818.

But how could a bilateral treaty between the United States and Britain give the Crown sovereignty over Indigenous peoples, including the Gitxsan, Wet'suwet'en, and Tsilhqot' in Nations, who were involved in Delgamuukw and Tsilhqot 'in Nation cases? As mentioned earlier, international treaties bind only the parties, and the Indigenous peoples of North America would have been outside the scope of American, British, and international law, at least until de facto sovereignty was acquired over their territories by one of those colonizing nations. ${ }^{18}$

In Haida Nation, a unanimous decision of the Supreme Court in $2004,{ }^{19}$ Chief Justice McLachlin acknowledged, for the first time, the pre-existing sovereignty of the Indigenous nations in British Columbia. ${ }^{20}$ But if they were sovereign, how could the Crown have acquired sovereignty over them by discovery, a treaty with the United States, or mere assertion? The Supreme Court has not provided any answer to this question. Instead, the judges seem to prefer to avoid it - apparently it is too political.

In Australia, the response of the High Court has been that the Crown acquired sovereignty by act of state whenever and wherever it purported to do so, and the courts can't question this - it is outside domestic courts' jurisdiction. ${ }^{21}$ This is a convenient way for courts to avoid the issue, but it doesn't mean the Crown's

\footnotetext{
${ }^{16}$ Delgamuukw v. British Columbia, [1997] 3 S.C.R. 1010 at para. 145.

${ }^{17}$ Tsilhqot'in Nation, above note 4 at para. 60.

${ }^{18}$ For further discussion, see Kent McNeil, "Negotiated Sovereignty: Indian Treaties and the Acquisition of American and Canadian Territorial Rights in the Pacific Northwest", in Alexandra Harmon, ed., The Power of Promises: Rethinking Indian Treaties in the Pacific Northwest (Seattle: University of Washington Press, 2008), 35.

${ }^{19}$ Haida Nation v. British Columbia (Minister of Forests) [2004] 3 S.C.R. 511 at para. 20.

${ }^{20}$ See also Mikisew Cree First Nation v. Canada (Governor General in Council), [2018] 2 S.C.R. 765, per Karakatsanis J. at para. 21.

${ }^{21}$ See Coe v. Commonwealth of Australia (1979), 24 A.L.R. 118; Mabo v. Queensland [No. 2] (1992), 175 C.L.R. 1, per Brennan J. at 31-32, Deane and Gaudron JJ. at 78-79; State of Western Australia v. Commonwealth (1995), 128 A.L.R. 1 at 12.
} 
acquisition of sovereignty was legal or legitimate - it just can't be questioned by the courts, whose jurisdiction depends on Crown sovereignty.

From a de facto perspective, the Crown clearly exercises jurisdiction over Canada today, and this de facto sovereignty is acknowledged by the international community, so the Crown must have de jure sovereignty in international law, but this does not mean it has de jure sovereignty in Indigenous law.

How did the Crown get sovereignty in international law? Not by conquest of the Indigenous peoples ${ }^{22}$ or by cession from them because the treaties did not purport to entail cession of sovereignty. And if Indigenous peoples were sovereign prior to the arrival of Europeans, not by settlement or effective occupation. That leaves prescription, but my understanding is that it requires acquiescence by the previous sovereign, ${ }^{23}$ and the Indigenous peoples in what is now Canada do not appear to have acquiesced in the Crown's acquisition of sovereignty.

In the Haida Nation case in 2004, Chief Justice McLachlin suggested that "preexisting Aboriginal sovereignty" on the one hand, and the Crown's "asserted sovereignty" and "de facto control of land and resources that were formerly in the control" of the Indigenous peoples on the other, have to be reconciled through honourable negotiations and modern-day treaties that deal with these issues. ${ }^{24}$ In my opinion, this is the appropriate way forward, but political will and commitment on the part of Canada is required for this reconciliation to become a reality.

Thank you for your kind attention.

\footnotetext{
${ }^{22}$ See Haida Nation, above note 19 at para. 25.

${ }^{23}$ See D.H.N. Johnson, "Acquisitive Prescription in International Law," British Yearbook of International Law 27 (1950): 332; R.Y. Jennings, The Acquisition of Territory in International Law (Manchester: Manchester University Press, 1963), 20-8; Yehuda Z. Blum, Historic Titles in International Law (The Hague: Martinus Nijhoff, 1997), 637; Shaw, above note 9 at 364-66.

${ }^{24}$ Haida Nation, above note 19 at paras. 20, 32. For detailed discussion, see Felix Hoehn, Reconciling

Sovereignties: Aboriginal Nations and Canada (Saskatoon: University of Saskatchewan Native law Centre, 2012).
} 